\title{
Historical analysis of U.S. electricity markets: Reassessing carbon lock-in
}

\author{
Sanya Carley ${ }^{\mathrm{a}, *}$ \\ a. School of Public and Environmental Affairs, Indiana University, Bloomington, \\ Indiana. \\ * Corresponding author: School of Public and Environmental Affairs, Indiana University, \\ 1315 East Tenth St., Bloomington, Indiana; sanya.carley@ gmail.com; 919-265-4651.
}

\begin{abstract}
This paper evaluates whether the U.S. electricity sector is directed away from carbonintensive technological lock-in, and which factors are contributing, or have potential to contribute, to a possible reorientation of the industry. With the application of a historical analysis of the electricity sector from the late nineteenth century through current day, this analysis finds that, although the industry still relies primarily on carbon-intensive fossil fuel operations, several recent trends indicate that the industry is becoming less carbon intensive, smaller in generation system scale, and more sustainable in operations. Crucial drivers - firm level interactions with technological change, industry leadership and market structure, government intervention and policy momentum, and citizen involvement and behavior patterns - that have traditionally shaped the structure, scale, and environmental footprint of the industry, have also played a prominent role in recent transformations. These results indicate that triggering or extraordinary events may not be necessary to initiate an escape from carbon lock-in in the electricity sector. Complete escape is not yet definitive, however, and it remains to be seen whether the industry is able to transform entirely before any significant climate change disturbances occur.
\end{abstract}

Keywords: Electricity; Carbon; Environmental History 


\section{Introduction}

The electricity market is changing and evolving, many claim, into one that will increasingly rely on sustainable fuel blends and smaller-scale operations (see, for instance, Budhraja, 1999; Flavin and Lenssen, 1994; Lasseter, 2006; Lovins, 2002; Li, 2004; Geller, 2003; Alanne and Saari, 2006; Abulfotuh, 2007). Developments in state and local policies to support renewable energy deployment and distributed generation may be identified as a harbinger of changes to come, an indication that the U.S. is ready to pursue a more sustainable electricity future. Yet, in contrast to these accounts, Unruh (2000) and others identify the sector's resistance to change, and its inability to break from a pathdependency based on fossil fuel and carbon-intensive operations in the generation and consumption of energy.

Is the U.S. electricity sector indeed on a path, as some have predicted, toward a lower carbon electricity future? Furthermore, if the sector is diverging from its path dependency, which primary factors are driving these trends? This paper explores these questions with the use of a historical analysis in effort to dissect the major developments in the sector's history that have contributed to its heavy reliance on carbon-intensive operations, and to assess whether, in light of this history and current developments, the electric industry is able, or on route, to escaping carbon lock-in.

The outline for this study is as follows. I begin with a review of Unruh's theory of "carbon lock-in" in section 2. In section 3, I present the methodological approach; in section 4, the history of the U.S. electricity sector as it relates to these issues; and, in section 5 , a review of the primary factors that have contributed significantly to carbon lock-in. I analyze modern day electricity operations in section 6 to detect trends related to carbon lock-in, or an escape from lock-in, and conclude in the last section.

\section{Understanding and Escaping Carbon Lock-in}

In "Understanding carbon lock-in," published in Energy Policy in 2000, Gregory Unruh presents the theory of carbon lock-in, the condition in which technological advancements, due to scale and learning economies, and institutional forces - including social, firm, and public institution responses - become co-evolutionary and interdependent. The combination of these forces can become self-perpetuating, and continually feedback to reinforce the system, a process that Unruh terms the "technoinstitutional complex" (or TIC), and can thus result in path-dependency. Over time, this path dependency generally forms an equilibrium state, or a quasi-equilibrium, in which alternative technological and institutional change happens incrementally, if at all (i.e., "lock-out"). In the case of energy technologies, which are the focus on Unruh's theory, TICs create "persistent market and policy failures that can inhibit the diffusion of carbonsaving technologies despite their apparent environmental and economic advantages" (817).

Unruh relates his theory to several aspects of U.S. energy markets, including the transportation, telecommunications, and electricity sectors. In illustration of the TIC concept as it applies to the electricity sector, Unruh provides a diagram, which is replicated and modified in Figure 1 below. This diagram, which is a simplified representation of electricity sector institutions and components, demonstrates the interdependencies that can, over time, establish path-dependency on carbon-intensive electricity generation and consumption. The lock-in cycle according to Unruh involves 
four main components: markets, firms, government, and consumers. Each of these components has its own internal cycle, which shapes the nature and progress of the entire system's feedback processes.

\section{Figure 1. Modified Depiction of Unruh's (2000) Electricity Sector Techno-Institutional Complex}

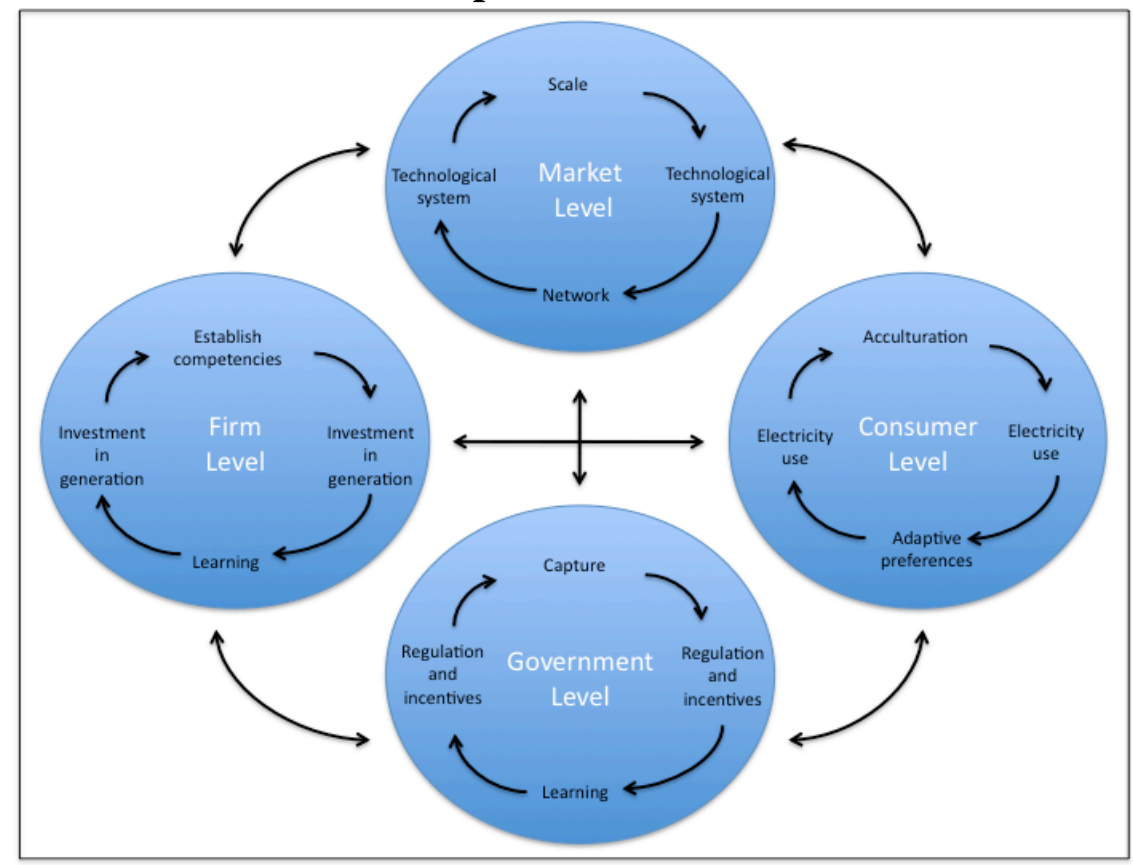

In a later analysis, Unruh (2002) poses the question of how to escape carbon lockin? Unruh argues that there are generally three policy approaches to overcoming environmental dis-utilities of technological systems: (1) only treat the emissions but not the greater system; (2) treat components of the process but maintain the overall "system architecture"; or (3) treat the entire system architecture (Unruh, 2002: 318). These three options, respectively, are summarized as end-of-pipe, continuity, and discontinuity. The feasibility of each of these options, however, is constrained by the boundaries of the current TIC, as Unruh explains, "When system growth and permanence has become institutionalized, as in the case of several fossil fuel based systems, some options can only be explored once the lock-in condition is overcome" (2002: 320). What, then, does it take to overcome lock-in so that energy policymakers and other actors can pursue one of these policy approaches? Toward these ends, Unruh posits that there are three possible mechanisms: incremental policy shifts away from the carbon lock-in equilibrium through the use of basic policy instruments; or an expansion or diffusion of information to facilitate awareness of the problems associated with carbon lock-in. What Unruh explains to be the most likely scenario, however, is that policymakers will have to wait for a "triggering" or "focusing" event to precipitate action and institutional change that is counter to a carbon lock-in equilibrium. In keeping with others' theories, large-scale institutional policy change often requires external shocks (March and Olsen, 1989; North, 1990) or "extraordinary events" (Cowan and Hulten, 1996). Unruh acknowledges, however, that " $[\mathrm{d}]$ espite these barriers, technological and institutional changes have 
occurred repeatedly in history...so readers should not assume that the current quasi-stable equilibrium is a permanent feature."

The present analysis takes Unruh's carbon lock-in theory as a starting place for analysis, with the following two-part research question: is the U.S. electricity sector on the path to escaping carbon lock-in; and which factors are contributing, or have potential to contribute, to a possible "escape" of the sector's quasi-stable equilibrium? In addressing this question, this study also considers whether Unruh's theory about the need for a "triggering" event to precipitate institutional change is valid in the case of the electricity sector. Or, alternatively, might it be possible that institutional changes can occur through the same processes that first established the equilibrium in the first place? Might the positive feedbacks that created the techno-institutional complex, based on carbon-intensive production and consumption of U.S. electricity, be equally able to reverse, or escape, lock-in?

\section{Methodological Approach}

The methodological approach employed in the present study is a historical analysis. The objective is to dissect major events and trends throughout the history of the U.S. electricity sector, and identify factors that have contributed to carbon lock-in and the quasi-equilibrium state of the electricity sector as it remained through the end of the twentieth century. Specifically, I identify trends at the market, firm, consumer, and government levels that have contributed to the techno-institutional complex that shapes Unruh's carbon lock-in theory. Following the historic account of lock-in, I analyze more recent trends in the sector to extract insights on potential future directions in which the sector may head, and to use this information to assess whether the sector is on route to escaping carbon lock-in.

The data and information gathered and synthesized for this analysis are secondary in nature, that is, historical studies that have been conducted already on electricity sector trends and formative events. I compile the historical assessments that shape this discourse via a literature review of relevant books, articles, and grey literature in the energy field, with efforts extended to collect a variety of perspectives and accounts. Secondary data are primary sourced from the Energy Information Administration, but include several other sources as well; all data used to support the arguments made in this paper are cited accordingly.

There are multiple advantages to this type of methodological approach. First, a historical analysis allows one to get a sense of changes over time, how transitions, major events, or key elements have shaped the sector in the past, and what kind of potential these same elements have to shape the market in the future. Second, this type of analysis allows one to consider all trends in the electricity sector, not just those that are specifically related to carbon policies, or could be easily summarized as a quantitative variable and inserted into an empirical model. Third, a historical analysis provides a greater context for understanding the phenomenon of carbon lock-in that is more rich and detailed than alternative research design approaches.

While there are several advantages to this type of analysis, it is nonetheless important to note that one must remain cautious in the interpretation of the findings and conclusions. A historical analysis can make no claims of causality, and is not capable of asserting information regarding the strength of associations between and among events, 
or between events and other factors. Also, as discussed above, the present analysis relies extensively on others' accounts of the historical foundations of the U.S. electricity sector, since no primary data or information was gathered in the preparation of this study; and the secondary nature of this compiled information may restrict or at least formatively shape the conclusions drawn in this paper. Proceeding with these precautions, I turn in the next section to a review of the history of the electricity sector, focusing in particular on the events and trends that have led to carbon lock-in of the sector.

\section{History of the Electricity Industry}

\subsection{Nineteenth Century Electricity: the Early Rise and Fall of Distributed Energy}

Prior to the 1880s, gas technologies were the most advanced lighting options in the United States; heat was provided by direct local combustion of wood or coal, and mechanical energy was provided largely by steam engines, watermills, and animal traction. Thomas Edison, working throughout the 1870s on the telegraph, the telephone, and the phonograph, soon thereafter produced direct current (DC) electricity to replace gas lighting with more efficient electric lighting (Hirsh, 1999). Generated at a small central station facility in lower Manhattan beginning in 1882, Edison's operation employed steam engines and generators and was linked to a wiring network that could transmit DC electricity for up to one mile. The first establishments to have electricity were hotels, opera houses, department stores, and theaters (Smeloff and Asmus, 1997); and eventually local governments purchased electricity to power public spaces, such as for street lighting (Patterson, 1999). Electricity was more expensive than gas lighting; only those private or public interests that were willing to pay the premium purchased electricity.

Within a couple of years of Edison's invention, however, the DC electricity model was challenged by Westinghouse and Nikola Tesla's alternative current (AC) design, which could transmit electricity in both directions within a circuit and over a significantly greater distance than DC's mono-directional current. The "battle of the systems," pitted Edison, advocate of DC, against Westinghouse and Tesla, advocates of AC. Edison eventually lost (Patterson, 1999).

By the 1890s, AC current became the predominant model of electricity transmission and, by 1893, AC-DC converters and transformers technologically completed the universal electricity system. With the advent of this new model and the concurrent invention of the steam turbine by Charles Parsons, electricity prices became more reasonable and operations expanded to meet the needs of new customers and new sectors of the market.

The electricity industry did not get fully off the ground, however, until the advent of the trolley. It was then, in the 1890s, that electricity operations fully captured a unique market that was met by steady demand. In 1895, Sacramento, California deployed the first non-distributed AC electrical application in which electricity was transmitted from a central source via high voltage lines (Smeloff and Asmus, 1997). On the whole, however, power production began small; dispersed generation units located close to the end-user were frequently deployed on a residential and industrial scale. The gradual growth of private power companies, the evolving sophistication of electricity technologies, and the use of larger, more centralized generation facilities for public services eventually led to 
the replacement of dispersed and distributed generation by large-scale generation systems.

Electricity prices remained fairly low during the late 1800 s, mainly due to consistent supply-side competition between various electricity technological inventions, including electric trams, trolleys, stationary electric motors, and the Welsbach mantle (Patterson, 1999), and demand-side competition by a growing base of end-use consumers. By the end of the century, the electricity industry in the U.S. was a fully functioning and continually expanding market, with individual actors that were rapidly acquiring market power.

The early years of the electric industry laid the foundation for subsequent market and firm level dynamics. With the new formation of the electric market, and the commercial deployment of various electricity technologies, consumer demand rose as consumers began to incorporate electricity into their daily patterns of life. The technoinstitutional cycles, therefore, at the market, firm, and consumer levels began in the earliest years of the industry's foundations. There was still possibility, however, for the industry to develop according to any number of different paths; that is, until the Progressive era locked in the market structure and the role of the government in oversight of the industry and the post-World War II era locked in the industry's reliance on largescale, centralized, fossil fuel generation.

\subsection{The Progressive Era: Public vs. Private Power Production}

During the 1890s and early 1900s, private utility companies expanded their market power through mergers and financial consolidation. Monopoly expansion was a prominent trend of the time and not unique to the electricity sector; although monopolistic power had become particularly pronounced in the electric sector. In effort to address these market abuses, municipal governments across the country developed their own power operations with city-owned plants and network facilities. By 1907 municipal power companies constituted roughly one-third of the nation's power suppliers (Hirsh, 1999).

Not all regions, however, responded to market power dynamics with the creation of public power entities. Others dealt with these issues via regulation. Samuel Insull, a personal secretary of Edison's, was one of the first advocates of a regulated electric industry. Insull, an owner of several utilities including Commonwealth Edison, had bought out numerous rivals and consolidated operations under one entity in the early turn of the century. Disinclined to regional competition, Insull explained to his businessmenpeers that a regulated industry would allow utilities to act as natural monopolies, unfettered by standard market competition and with additional freedom to pursue economies of scale in operations. Insull rallied support from other prominent businessmen, such as J.P. Morgan, to lock-in the notion of a regulated industry among the private industry leaders, state officials, and the public (Smeloff and Asmus, 1997).

In response to Insull's advocacy efforts, local municipalities across the U.S. began to grant exclusive charter territories to individual power companies. ${ }^{1}$ These developments

\footnotetext{
${ }^{1}$ These territory franchises generally involved certain utility obligations, such as universal, nondiscriminatory, and reliable service, and additionally included other regulatory measures to check monopolistic abuse (Patterson, 1999). Regulators set electricity rates under territory franchises to cover utility's operating expenses and provide an additional "just and reasonable" return on their investments.
} 
marked the gradual victory of private firms in the industry due to economies of scale, business expertise, and political power and influence, and precipitated the movement of the market level component of the techno-institutional complex down the path toward lock-in.

While other countries facing electricity market expansion encouraged cooperative utilities to generate and distribute public power (Patterson, 1999), the U.S. electricity sector became increasingly more privatized and state-regulated. Amidst the Progressive movement in the U.S., whose political leaders attempted to condemn political corruption and corporate crime, emerged a "regulatory ideology" within Wisconsin and New York that encouraged state regulation of the electricity industry and sought to enforce governmental control over a complex natural monopoly (Hirsh, 1999). Regulation of the industry, in other words, provided security and confirmed market power for utilities that otherwise would not be guaranteed under non-regulation. ${ }^{2}$

Other states followed Wisconsin and New York's lead and drafted legislation that mandated state regulatory commissions to oversee day-to-day operations within the electricity sector, thereby reinforcing the connection between markets and firm level developments in the formative years of the techno-institutional complex. The majority of state commissions' regulatory authorities were granted during the Progressive era, such as the responsibility for regulating the retail sale of electricity, as well as the distribution, siting, construction, operations, and rate-setting of electricity utilities (Brennan et al., 2002). Utility commissions were also granted quasi-legislative powers, the authority to impose penalties for non-compliance with their rules, and quasi-judicial power (Hirsh, 1999).

By the end of World War I, the electricity sector was the biggest industry in the country. Electricity companies continued to expand by facilitating mergers and attracting significant private investment. Electricity demand grew, particularly in the aftermath of World War I, while electricity prices declined simultaneously.

In 1920 Congress passed the last major federal Progressive-era legislation, the Federal Power Act (FPC), which established the Federal Power Commission (now the Federal Energy Regulatory Commission, or “FERC”). The Federal Power Act established federal control over wholesale electricity operations, interstate gas and oil operations, and across-state transmission services, among other responsibilities. This act formally divided state and federal authority over operations within the electricity sector (Brennan et al., 2002).

In just over three decades, electric power generation evolved from a never-heardof technology intended by Edison to power residential lamps into one of the biggest and most powerful industries in the country, on par with the railway, water, and telephone industries. Progressive era reformers and private capitalists were the most significant participants in this transformation. In pursuit of economic development and the curtailment of government corruption, policymakers of the Progressive era framed the new shape and scope of the electricity market: a state-regulated industry in which large,

Patterson describes the new method of electricity operations: "each system became a local 'fiefdom,' making its own decisions within its own local framework of laws and regulations and with a distinctive and intimate relationship with the relevant government" (1999: 45).

${ }^{2}$ One such power was ability to use eminent domain to secure private lands for public purposes, a privilege that had previously been granted only to the government (Hirsh, 1999). 
independent utility companies owned the majority of the market's power production facilities and sought ever-increasing means of generation and distribution efficiency. The structural form of the sector, including the interactions between government, firm, consumer, and market levels of the completed techno-institutional complex, has remained largely the same until recent decades, when similar questions have resurfaced regarding market power, competition and incentives to innovate, public versus private responsibilities, and the consumers' role within the sector.

\subsection{The New Deal: National Control and Rural Electrification}

By the early 1930s three holding companies provided the majority of the U.S.'s generation capacity (Patterson, 1999). Concerned with the growing, unchecked power of the industry and various holding company abuses, President Franklin Roosevelt and Progressives in the Congress sought to increase federal oversight of the industry and to challenge the private, regulated-utility model of operation.

Frustrated with overtly profit-seeking utility operations, Roosevelt sought means to allocate public power authority to public organizations, which he accomplished via rural electrification and large-scale hydroelectricity initiatives. First as governor of New York, Roosevelt created the Power Authority of the State of New York, and later as President of the United States, Roosevelt developed federal power agencies that mixed socio-economic policy with electricity operations. From early in his presidency, Roosevelt channeled federal money toward large-scale hydroelectricity, flood control, and water management projects. In 1933, Roosevelt founded the Tennessee Valley Authority (TVA), which he charged with the mission to provide electrical power to all citizens in the Tennessee Valley and surrounding areas. Roosevelt initiated other water resource developments as well, including Bonneville Dam, Boulder Canyon Dam, and the Grand Coulee Dam, among others. These projects not only provided federal public power but they also acted as a "yardstick" against which private prices for electricity could be compared to assess whether prices were reasonable (Smeloff and Asmus, 1997). In 1935 Congress created the Rural Electrification Administration (REA) as part of the Rural Electrification Act, which helped finance cooperative generation and distribution companies that served rural farmers and other isolated customers. The REA most notably constructed federally financed transmission networks across the Midwest, a result of emerged the cooperative utility ownership model (Patterson, 1999).

In 1935 Congress enacted the Public Utilities Holding Companies Act (PUHCA) as a consumer-protection law. PUHCA forced large electric holding companies to divest their holdings and also tightened regulation over utilities' jurisdictions and investment procedures. Through PUHCA legislation, the federal government assumed a larger role in the regulation of the electricity sector, especially under circumstances in which power crossed interstate boundaries (Patterson, 1999).

The New Deal period contributed to the techno-institutional complex of the U.S. electricity sector by further expanding the role of government in the day-to-day involvement of the industry's supply side operations. By the end of this period, the public sector controlled a portion of the industry, and established its role as a necessary participant to ensure electricity access and affordability to American citizens.

\subsection{Post World War II: Reddy Kilowatt and Electricity’s Heyday}


During and following World War II, the electric sector was marked by unprecedented growth and expansion. Fueling this growth, electricity demand steadily rose throughout the late 1940s and into the early 1960s - by roughly seven percent per year-while a greater number of electronics flooded consumer markets and mainstream culture. Electricity companies continued to encourage greater energy consumption; concurrently, utility companies sought to transform the consumer image of electricity into one based on ease of living and attainment of family-oriented lifestyles. Personifying the industry's services, electricity companies produced ads that featured Reddy Kilowatt, an electricity network in the shape of a man, who could guarantee "better living through electricity" (Patterson, 1999: 58). Models of "all electric homes" also emerged through similar electricity company ad campaigns.

In response to rapidly increasing demand for electricity, utility companies grew both within and outside of their own businesses. Separate companies formed "power pools" as a method of trading electricity capacity back and forth to adequately respond to changes in electricity load. Within their own businesses, power companies sought larger and more centralized physical plants. Utilities expanded operations and built one after another base-load coal power plants. Steam turbine technologies continued to evolve, thereby helping large power producers realize greater economies of scale. A variety of energy sources continued to experience declining costs as well, including coal, diesel, oil, petroleum, and natural gas, although natural gas was not a popular source of supply until the late '70s. Larger, more centralized power plants became increasingly more efficient, while smaller, less efficient units were edged out of the market or held in reserve for peaking power. As long as energy demand continued to rise, increasingly larger power plants paid off. An average low-cost power plant in the 1970s was 20 times larger than one built in the 1930s (Smeloff and Asmus, 1997). The largest electrical generator in 1903 was a 5 MW unit, transformed into a $200 \mathrm{MW}$ unit by 1930, a 500-1200 MW unit by the 1960s, and, finally, a $1400 \mathrm{MW}$ unit by the 1970s (Lovins et al., 2002).

Concurrent improvements in various transmission and distribution technologies allowed central stations to locate further away from the end-use costumer. By the 1970s, power plants could be located as far away as $500 \mathrm{~km}$ from the end user (Patterson, 1999). The most cost-efficient method of producing electricity during the 1950s and 1960s was with the largest power plants, delivered via AC distribution networks that spanned the greatest distance possible (Patterson, 1999). Economies of scale allowed for cheap electricity, which in turn helped fuel economic growth and enhance consumer demand for electricity. ${ }^{3}$

By the mid-1960s, however, the growth in thermal efficiency of these power plants began to level off, which prompted the industry to turn toward nuclear technologies. Heavily endorsed by General Electric and Westinghouse, nuclear energy

\footnotetext{
${ }^{3}$ Municipal utilities and cooperatives, having gained some footing in the industry during the 1930s and 1940s, eventually found that they had to fight the large, central plant model for any market power. Sacramento Municipal Utility District (SMUD), for instance, emerged in 1946 after over two decades of citizen and community leaders' insistence that, according to the Federal Power Act, municipal utilities should have a legal priority to build hydroelectric operations (Smeloff and Asmus, 1997). Hydroelectric power production increased dramatically through federal subsidies for multi-purpose dam construction in the 1950s, but large-scale hydropower development opportunities were largely tapped out by the mid1960s. Most public utilities, most notably the TVA, instead followed the private industries' model: invest in large central-station coal and oil power plants (Smeloff and Asmus, 1997).
} 
made its debut among civilian electric companies in the early 1960s. The first nuclear facility was built by the Jersey Central Power and Light Company, which generated electricity at a price that was economically competitive with traditional fossil fuels (Smeloff and Asmus, 1997), although this competitiveness was predicated on federal subsidies and liability insurance protection under the Price-Anderson Act. By the late 1960s, nuclear facilities were widely used across the country, owned and operated by many public and private electricity companies.

The post-WWII period of the industry's history was one of the most significant contributors to carbon lock-in. In particular, the post-WWII period was a time of substantial electricity infrastructure and market expansion, all components of which reinforced the model of large-scale, centralized fossil fuel and continuously increasing in capacity size electricity operations, and a firm business model that based profits on supply-side expansion. This period also witnessed the expansion of the coal industry in the electricity market; coal generation quickly grew in market share, as the coal industry entrenched itself near the center of the technical and institutional co-evolution of the industry.

\subsection{The Industry meets its Biggest Challenges: the Environment, Diseconomies of Scale, and Economic Risk}

Toward the end of the 1960s, the industry's outlook took a notable turn. As a result of Johnson's Great Society programs and the Vietnam War, U.S. inflation began to rise. A concurrent increase in interest rates made capital borrowing more expensive and the 1973 Arab oil embargo contributed further to rising inflation. Between 1973 and 1979 , the price of oil went from $\$ 3$ per barrel to $\$ 30$ per barrel. Inflation and high interest rates affected the short-term economic stability of utilities, since many electric utilities held a variety of investments in new and existing central-station power plants. These economic conditions alone may not have been enough to compromise the industry; but in conjunction with the energy crises of 1973 and 1979, and the burgeoning environmental movement, the industry faced unprecedented challenges.

With approval from their respective state regulatory commissions, utilities were able to pass the higher costs of investment on to their consumers, who protested the higher rates that had as much as doubled in some regions (Patterson, 1999). Citizen action groups mobilized in different regions across the country and lobbied for reduced rates. Consumers also responded to electricity price increases by reducing their demand for electricity, resulting in a drop from an average of 7 percent growth per year to a 2 percent growth (Patterson, 1999). A reduction in demand reduced significantly the need for more power plants, during a time in which hundreds of power plants were being built and financed across the country. These planning and investment uncertainties further wounded the electricity sector.

Concurrently, the environmental movement in the U.S. was gaining momentum. By the late 1960s, environmental groups had launched a series of campaigns that targeted different aspects of the electricity market, including air pollution, waste disposal, chemical-use and discharge, nuclear use and disposal, and water pollution. A broad coalition of environmental activists continued to push the federal government to regulate industries that contributed deleterious effects on human health and safety. 
In response to public unrest, the federal government became actively involved in the electricity industry through direct regulation of the sector's outputs and standard operations. Starting with the National Environmental Policy Act (NEPA), signed into law by President Richard Nixon on January 1, 1970, the government established their expanded regulatory role within the sector. NEPA created the Council of Environmental Quality and mandated the use of environmental impact statements for infrastructure and development projects that require government approval or financing. Following NEPA were a series of air pollution acts - including the Clean Air Act of 1970 and the 1977 Clean Air Act - which increased the costs associated fossil fuel operations, particularly in the case of coal, and further increased the cost of electricity. The Department of Energy (DOE) was also created in the late 1970s, charged with a mission to oversee energy security, research and development initiatives, and energy supply issues. These developments represented the first federal attempts to incorporate environmental considerations into electricity policymaking and regulatory oversight.

Federal presence increased in the sector, as did state and utility commission oversight. This combination of a multi-level government presence altered the power dynamics within the industry, as Hirsh explains: "utility managers felt constrained by the growing web of environmental legislation and regulation, and they effectively lost their former ability to make almost unilateral decisions regarding the location, design, and construction of power plants" (1999: 69).

Following the first energy crisis and the rapid evolution of the environmental movement, President Jimmy Carter launched one of the largest energy campaigns the U.S. had experienced since the 1930s. Influenced by works of E. F. Schumacher and Amory Lovins ${ }^{4}$, Carter's energy initiatives focused primarily on diversifying fuel sources and reducing consumer demand. After assuming office in 1977, Carter championed the Power Plant and Industrial Fuel Act and the Natural Gas Policy Act, which sought to prohibit the use of oil and natural gas in new power plants and to deregulate the price of newly discovered natural gas, respectively. Carter then signed the Public Utility Regulatory Policies Act (PURPA) as part of the National Energy Act of 1978.

In Section 210 of PURPA, utilities were required to connect qualifying facilities (QF) - small generators using non-fossil fuel energy sources and cogenerators - to the transmission grid. ${ }^{5}$ Under PURPA, the Federal Energy Regulatory Commission was granted the authority to decide whether a QF is held to the same regulations - including utility rate structuring, financial obligations, and organizational structure - as traditional utilities (Hirsh, 1999). The actual implementation of PURPA, however, was left up to

\footnotetext{
${ }^{4}$ E.F. Schumacher's Small is Beautiful, written in 1973, emphasized the importance of developing energy infrastructure within the scale of actual need. Following Schumacher's publication, Amory Lovin's "Energy Strategy: The Road Not Taken" was published in Foreign Affairs in 1976, which advocated for a departure from traditional large-scale power production, toward a "soft energy path" based on renewable energy, energy efficiency, and a different scale and quality of production (Lovins, 1976). Lovins discussed how rate-payer resistance to raising rates would prevent utilities from building more centralized power plants; a solution to this supply-demand disconnect, Lovins explained, would require the U.S. to pursue a soft-energy path based on a "least-cost approach" to electricity generation that supports more distributed sources and a greater role for efficiency.

${ }^{5}$ PURPA required that utilities purchase power from QFs at a price not to exceed the "avoided costs" of the power that would be produced in the qualifying facility's absence.
} 
state regulators. The passage of PURPA thereby transformed utility commissioners' roles within state electricity markets, granting them greater discretion in market decisions and power dynamics (Hirsh, 1999). ${ }^{6}$

The most immediate effect of PURPA was the industry's new promotion of the jet engine, otherwise known as the combustion turbine. Combustion turbines, when used in cogeneration plants, are exceedingly more efficient than traditional turbine technologies; more than 75 percent of the energy potential of natural gas can be captured with cogeneration combustion turbines (Smeloff and Asmus, 1997). Cogeneration plants, however, are relatively small in size compared to traditional power plants. Largely as a result of PURPA, the amount of cogeneration capacity in the U.S. increased four-fold in the decade and half following its passage (Hirsh, 1999). PURPA additionally gave rise to wind and industrial steam technologies, promoted the re-entry of small hydro dams, and encouraged research and development efforts in other technologies, such as the fuel cell, solar troughs, and fluidized bed combustion boilers (Hirsh, 1999).

PURPA's Section 210 also encouraged industrial and personal applications of small-scale generation facilities. Industrial leaders and independent power producers, as a result of PURPA, began to locate small electricity modules next to the actual load demands, which marked a divergence from the industry's predominant model of large, centrally located power plants.

Additionally, PURPA reduced barriers to entry in the electricity generation market and was the first flavor of deregulation that the electricity sector had experienced. Independent power producers, for instance, were granted access to retail markets under PURPA stipulations and were not necessarily required to charge traditional rate-based prices for electricity. Hirsh (1999) provides an analysis of PURPA's effects on the electricity sector. In his analysis, Hirsh explains that PURPA contributed to the "disintegration" of the "traditional structure of utility systems" by reducing barriers to entry within the generation sector, introducing free-market principles, and changing power demographics within the industry (119).

The enactment of PURPA, and the subsequent changes in electric sector operations that ensued as a result of its passage, represented both a continuation of the path dependency of the industry as well as a divergence, or threat, to the industry's quasiequilibrium state. In continuation of the pre-established path dependency, PURPA reinforced the use of fossil fuels as the primary source of energy supply. In divergence of this path, PURPA encouraged the deployment of new supply-side technologies, including various renewable resources; led to an increase in the use of smaller-scale generation units; and affected the number and types of market actors within the industry. It was not yet clear at this time, however, which PURPA trends would prevail and whether the new threats to the industry's equilibrium would gain enough momentum to challenge the stability of the techno-institutional complex.

\footnotetext{
${ }^{6}$ Although PURPA is best known for mandating QF access to the grid, this was not its primary objective. PURPA was largely intended to encourage state utility regulatory bodies to consider load management options and retail price structuring that would encourage efficiency and conservation measures; as a result, many utility commissions across the country mandated that utilities implement conservation programs before building new power plants.
} 


\subsection{0s: A Decade of Demand-side Exploration}

By the late 1970s and early 1980s, the central-station model of electricity operations was under heavy scrutiny. Oil prices were found to fluctuate drastically; coal operations contributed to environmental problems; and nuclear energy was increasingly the focus of citizen protests. The Three Mile Island nuclear accident in 1979 completed the shift in the public's perception of nuclear energy. Before Three Mile Island, nuclear energy was less efficient and more difficult to site than other traditional fuel sources but produced electricity at a relatively low cost. Following the nuclear scare at Three Mile Island, as well as the fire at TVA's Brown's Ferry, nuclear energy became a risky investment and exceedingly unpopular in the public's eye. As a consequence, nuclear sites were no longer developed after the 1970s in the United States.

Between 1984 and 1987, oil prices began to fall again. Natural gas became a leading energy source and combined cycle technologies using natural gas became widely deployed. The building of coal and nuclear facilities slowed down dramatically, from an average of 268 plants per year since the 1940s to a total of 22 plants throughout all of the 1990s (Lovins et al., 2002). Combined cycle and natural gas plants began supplanting traditional coal and nuclear facilities. Meanwhile, independent producers entered the market to develop cogeneration and renewable energy systems. These trends demonstrated a new form of economies of scale in the electricity sector: economies from the manufacturing of generation units (Patterson, 1999; Hirsh, 1999).

Also in the 1980s, some state public service commissions began to require that utilities adopt integrated resource planning (IRP) programs that relied on demand side management (DSM) energy conservation techniques. DSM actually began in the 1970s, following the oil crisis, when utilities offered educational information to consumers about electricity conservation techniques via energy audits, printed materials, and personal communication (Nadel and Geller, 1996). As DSM programs evolved and became more elaborate, the obligations - both financial and consumer-service-assigned to utilities also became more extensive. By the late 1980s, when oil and gas prices fell and the perceived risk of limited energy supplies fizzled out, many utilities grew reluctant to promote DSM programs (Patterson, 1999). Utilities also demonstrated reluctance because they has overbuilt electric generating capacity in the 1970s and, given the slower rate of demand growth in the 1980s, they had less incentive to continue promoting demand reduction. Both DSM and IRP programs offered a disincentive to utilities: discouraging consumption only reduces profits. Utility resistance and the general recognition of this disincentive led to lengthy, multi-actor discussions in the late 1980s and early 1990s about how to create more innovative DSM programs. These discussions resulted in new DSM programs that provided direct financial incentives for conservation, and also made state commissions directly responsible for environmental management (Hirsh, 1999). Utilities' resistance to DSM and IRP programs, however, continued into the 1990s and helped fuel discussions regarding market power and the possible need for market liberalization (Hirsh, 1999).

By the end of the 1980s, the techno-institutional complex of the electric sector still maintained carbon lock-in. At the firm level, the majority of electric businesses continued to invest primarily in fossil fuel technologies. At the market level, although the scale of some operations was decreasing, the market tended to favor centralized operations, and the transmission and distribution infrastructure that supported this scale 
of operations. At the consumer level, the electric industry witnessed a rebound in electric demand post-1970s, when energy prices began to fall again. At the government level, although policies and regulations enacted during the 1970s and 1980s sought to improve the environmental performance of electricity systems and operations, the effect of the various policies enacted by the end of the 1980s was not substantial enough to alter the institutional and technical feedbacks at the firm, market, or consumer levels; nor were these policies able to alter significantly the costs of fossil fuel-based electric generation so as to represent the full social costs of fuel extraction, production, and distribution. These combined forces, therefore, continued to perpetuate carbon-intensive operations within the industry. At the same time, however, the electric industry was evolving and changing in several other regards, including the influx of new market participants, the increase in investment of less carbon-intensive new energy supplies, and the increase in regulation oriented toward environmental and market structure considerations. Although these changes did not threaten the quasi-equilibrium state of the industry, these ongoing developments in scale, scope, and institutional make-up prompted discussions among industry leaders and policymakers regarding the economic composition of the industry at large, and eventually led to new rules and regulations aimed at opening portions of electric sector to competition.

\subsection{The 1990s: A Time of Restructuring}

The Energy Policy Act of 1992 (EPAct) and FERC's Orders 888 and 889 helped “extend PURPA's open-access policies to all generators" (Brennen et al., 2002: 105) and facilitated a growing base of market actors, particularly in wholesale power markets.

EPAct established exempt wholesale generators (EWS), which are electric generators that can be owned by a utility, a company that is independent of utilities, or by a holding company. Orders 888 and 889, established in 1996 to initiate EPAct stipulations, required that all utility companies provide nondiscriminatory transmission access to any generation company. In the case that there is not enough transmission capacity for a generator to plug into the grid, Order 888 required utilities to expand capacity to allow these generators access. Order 888 also allowed independent system operators to manage transmission lines and ensured nondiscriminatory access to unaffiliated generation companies. Utilities were required to "unbundle" their transmission, ancillary services, and generation rates; and as established in FERC Order 889, utilities were required to provide information on the ongoing prices of each of these services. FERC's Order 2000, following Orders 888 and 889 and issued in 1999, mandated that power companies commit all transmission assets to a regional transmission operator or explain why they are not doing so (Brennan et al., 2002).

The aforementioned events of the 1970s spurred discussion of market power and competition within the industry and eventually led to more complex discussions, beginning around 1992, of market structure and the potential for restructuring. Discussions focused on whether competition in the industry could improve efficiencies in supply-side costs; whether restructuring could effectively balance and reduce electricity rates in different states; and whether restructuring would encourage innovation and allow advanced supply-side technologies to capture a greater share of the market (EIA, 2000; Joskow, 2008). By 1994 these discussions became widespread and involved a mix of industry leaders, state and federal utility organizations, and third-party actors. 
Policymakers across the country began to draft laws and policies that aimed to disband the traditional monopoly structure and increase competition in electricity markets. In early 1994 California created a restructuring Blue Book proposal for their retail electricity market. California enacted their restructuring plan in August 1996; within six months, three other states also enacted restructuring plans to make retail electricity markets competitive (Hirsh, 1999). ${ }^{7}$

The effects of deregulation have been varied. Since the late 1990s, almost half of the states have adopted some form of restructuring. Although one of the main goals of restructuring is to reduce the cost of electricity, deregulation has resulted in unusually high prices and rolling blackouts in some states. Other states, such as Pennsylvania, have more effectively restructured their markets to allow for competition and to maintain lower prices (EIA, 2000). Deregulation allowed independent companies to enter state markets and hold an increasing share of net generation. Investor owned utilities have divested an increasing number of generation assets and have increased merging activities as a result of deregulation. Deregulation also helped some new technologies, such as realtime-pricing or bidirectional distribution automation, gain attention (Lovins et al., 2002). Deregulation trends have also raised important questions about the interaction between the electric industry and the environment (see Palmer, 1997; Sanyal, 2007, for example): will a competitive market be better for the environment; will utilities and independent power producers have an incentive to promote renewable energy; will market reforms encourage greater deployment of low-carbon distributed generation systems?

Unruh's account of carbon lock-in was published in 2000, following the historical foundations of the industry reviewed thus far. By the end of the $20^{\text {th }}$ century, the electric industry in the U.S. still relied primarily on fossil fuel generation to satisfy electricity demands, with guiding market objectives to keep electricity costs low and reliability high. These new changes in the sector's structure represent a fairly significant shift from past trends, but do not necessarily challenge carbon lock-in, or the feedbacks between the technical and institutional components of the industry.

\section{A Review of Industry Drivers}

The history reviewed thus far captures the process - technological and institutional feedbacks - that the U.S. electricity sector experienced, the result of which is the quasi-equilibrium state of carbon lock-in, as it existed up through the twentieth century. In review of this history, it is evident that no single element solely shaped the structural and institutional changes within the electricity sector, and gradual transition toward carbon lock-in, through the decades. Instead, several factors shaped the structure of the industry through the years, including firm, market, consumer, and governmental factors. These factors collectively led the electricity sector toward a quasi-equilibrium state, in which generation and consumption operations were driven substantially by fossil fuel-based, carbon-intensive energy technologies.

At the firm level, technological drivers significantly shaped developments within the sector since its inception. From the advent of AC-DC converters and electric motors - through large-scale hydroelectric projects, coal combustion technologies, advances in thermal efficiency, transmission and distribution infrastructural

\footnotetext{
${ }^{7}$ The general restructured model maintains regulation of transmission and distribution operations but turns the generation side over to a competitive market.
} 
improvements, and nuclear fission technologies - technological developments made centralized fossil fueled power the most economically-efficient form of operation. When efficiency gains in thermal technologies leveled off in the mid- to late-' 60 s the industry invested more heavily in nuclear technologies; and when the efficiency of natural gas generators increased in the 1980s the industry built natural gas and combined cycle systems at a rapid rate. Throughout this entire history, firm investments in technology have been based on economies of scale; and these investments have favored consistently large-scale power plant operations that tend to use fossil fuel as a primary energy source.

At the market level, dating back to Samuel Insull, who effectively convinced both public and private industry leaders to adopt a regulated market model, industry leaders have exerted significant influence over promoting or impeding change within the electricity sector. Under a regulated electricity market, private natural monopolies are granted exclusive market power, though state and federal governmental institutions heavily regulate their practices. Utilities have reaffirmed this market power by working to keep production costs low, securing exclusive service territories, providing reliable service, controlling transmission and distribution infrastructure, and lobbying at the state and federal level to protect their interests. Private companies have also maintained control within the market by facilitating partnerships, mergers, acquisitions, and power pools in response to market opportunities and changes.

Government intervention has also shaped the structure of the industry. Throughout most of the sector's history, government intervention has been reactive, primarily aimed at checking market power. These trends are evident in the reforms made in the Progressive era to establish explicit government regulation, in New Deal PUHCA and REA legislation, and in various forms of legislation that emerged in the 1970s, including the Clean Air Act of 1970 and the formation of NEPA. These policies and regulations shaped the institutional structure of the industry, and supported, if not dictated, the industry's quest for the lowest cost, most reliable, and highest quality energy services. Starting around the mid-70s, direct government intervention within the sector became more proactive, with a few exceptions due to "pendulum politics" (Andrews, 1999). Starting with PURPA in 1978 and continuing with DSM and IRP regulations in the ' $80 \mathrm{~s}$, government involvement in the industry has been less focused on restricting market forces or reacting to circumstances of market power. Instead, government involvement has been geared toward transforming the industry by facilitating opportunities for technological innovation and open market entrance. These more recent policy and governance developments, however, have not altered significantly the feedback between institutional and technological forces within the industry, nor led the industry to stray from operations that continually support carbon-intensive generation sources.

Consumer level factors that have shaped the operations of the industry include both advocacy work and behavioral responses. Consumers responded to cheap electricity rates and rapidly expanding energy supplies - sourced primarily from fossil fuels - in the post-WWII era by increasing energy demand and adopting energy-intensive behavioral patterns. Consumer demand for cheaper rates and environmental responsibility encouraged government regulation in the 1970s and again in the 1990s. The greater public's involvement in the environmental movement of the 1970s helped encourage the adoption of PURPA and promotion of energy efficiency programs. Citizens' protests over 
rising electricity rates, as well as a growing interest in electricity market competition by leading think tanks and other researchers, spurred a movement in the industry toward deregulation in the 1990s. Falling energy prices and a consequential reduced consumer interest in conservation efforts in the late 1980s, on the other hand, impaired the effectiveness of DSM and IRP programs.

This complex combination of institutional actors and drivers fundamentally shaped the structure of the electricity sector through the end of the twentieth century. As I examine current events within the sector and consider possibilities for a break from carbon lock-in, I return to these defining factors to gather deeper insights about new developments and their future ramifications.

\section{Electricity in the $21^{\text {st }}$ Century}

\subsection{New Trends in the Electric Industry}

One of the most prominent developments within the electric sector since the beginning of deregulation has been the Energy Policy Act of 2005, which, on the whole, produced only nominal effects on the structure and scale of the electric industry. The Energy Policy Act was enacted by the $109^{\text {th }}$ Congress after four years of congressional deliberation, and signed into law by President George W. Bush in August, 2005. The adoption process made evident that energy policy had, through the years, become a partisan, as well as regional, issue. Energy policy had come to involve diverse stakeholders and different market actors with conflicting interests, multiple levels of government involvement and regulations, and intricate connections to environmental and economic development.

The 2005 energy bill extended the federal production tax credit for wind and biomass, and also extended additional tax credits to other forms of renewable energy development. However, it failed to adopt a national renewable electricity standard or address global warming through regulation, and also repealed PUHCA. The bill primarily supported fossil fuel generation and expansion, with a disproportionate amount of funding allocated to nuclear, coal, oil, and gas (UCS, 2005). The Union of Concerned Scientists (2005) estimated that out of the total $\$ 14.5$ billion tax provisions within the bill, 39 percent of the tax package funds went to nuclear, 31 percent went to fossil fuels, and 9 percent went toward renewable energy development and deployment. The remaining 21 percent went elsewhere, the majority of which toward energy efficiency.

Other electricity sector developments in the early twenty-first century have been less pronounced but potentially more formative for the long-term structure of the industry. These events include the overlap of electricity and environmental policy through public discussions of global climate change, the emergence of state government leadership in progressive energy policy, and the rise of renewable energy as a viable source of energy supply.

In the early 2000s the industry experienced a resurgence of attention devoted to the environment, reminiscent in part of the 1970s, but this time due to global discussions of climate change. Climate change discussions emerged in the early 1990s, when the Intergovernmental Panel on Climate Change (IPCC) published their first Assessment Report (Patterson, 1999). Discussions of climate change, and the potential for a coordinated, global effort to mitigate its effects, increased throughout the 1990s. Eventually the causal link between electricity emissions and climate change, and also 
between climate change and environmental and human health in turn, became widely regarded, though not universally accepted, as fact. The recognition of this connection has led many industry leaders and government bodies to consider seriously the scope and scale of traditional electricity operations. While no federal regulatory measures that aim to restrict carbon emissions have been adopted in the U.S. thus far, and while few utility companies have independently sought to devise energy portfolios based on carbonneutrality, several disconnected efforts have been made to address the connection between climate change and electricity production.

The majority of these efforts are based at the state level. Many state governments across the country have begun to implement policy incentives and regulatory measures that aim to increase low- or no-carbon energy technologies, expand energy efficiency programs, reduce carbon emissions that come from electric generation, and provide incentives for consumers to purchase distributed generation systems. Many states have adopted renewable portfolio standards (RPS) and energy efficiency resource standards (EERS) to increase the percentage, and total amount, of renewable energy and energy efficiency, respectively, in state's generation portfolios. As of 2010, 45 states have either a mandatory or voluntary RPS policy; 24 states have some type of an EERS policy, either mandatory or voluntary, and connected to RPS legislation or as stand-alone legislation (NC Solar Center, 2010). Studies have found that these policies have thus far effectively increased total wind energy development and deployment (Langniss and Wiser, 2003; Menz and Vachon, 2006; Carley, 2009), although the effect of these policy instruments on the percentage of renewable energy out of total generation was, as of 2006, still relatively insignificant (Carley, 2009). The majority of states have also enacted net metering and interconnection standards in attempt to facilitate relationships between utilities and independent electricity power producers and end-use customers that would like to invest in distributed generation. Additional grants, loans, rebates, buy-back incentives, and tax incentives offered by different states provide further incentives for the deployment of both small-scale and large-scale renewable electricity systems, as owned by the end-use consumer. Equipment efficiency standards, as well as building codes, also aim to increase energy efficiency and end-user electricity savings.

Over the last decade, many private utilities and independent companies across the country have initiated green marketing programs. These programs represent an attempt on behalf of utilities and not-for-profits to respond to consumer advocacy for greater renewable energy deployment. Green power programs allow consumers to pay an extra premium on top of their regular electricity bill for shares of renewable energy. This premium is designed to cover the extra cost of renewables, which displaces a portion of the dispatched fossil fuel power with renewable power. As several studies conclude, consumers have expressed consistently a willingness to pay more for clean energy, but as of 2004 green pricing programs had very low participation rates of roughly one to two percent on average (Swezey and Bird, 2001; Wiser et al., 2001; Wiser et al., 2004). These rates are, however, rising (Bird et al., 2008), as consumers grow more aware of and concerned about climate change, and as more utilities choose to offer green marketing options. As of 2008, approximately 983,000 customers, including both residential and non-residential, participated in green marketing programs (EIA, 2010b).

The U.S. electricity sector, in its current form, is still heavily dominated by centralized fossil fuel power production, owned and operated predominantly by a select 
group of private industry leaders. In the year 2009, the electric industry built the largest amount of new operational coal capacity, for a total of 3,218 MW, since 1991 (Shuster, 2010). As of this same year, 44.6 percent of the total electric generation in the U.S. came from coal, 20.2 percent from nuclear, 23.3 percent from natural gas, 6.9 percent from hydroelectricity, 3.6 from percent renewables, and 1.0 from percent petroleum (EIA, 2010). Graph 1, below, demonstrates the mix of electricity generation sources, by percentage, as of 2009. Graph 2 demonstrates trends in U.S. electricity generation sources over time. Over the past decade, from 1997 to 2007, hydropower has declined from 10.2 to 6.9 percent of the total generation and coal has declined from 52.8 to 44.6 percent. Renewable energy generation has increased by more than one percent, from 2.2 to 3.6 percent; while natural gas has increased by roughly 10 percent (EIA, 2010). As these graphs reveal, U.S. generation is still primarily reliant on fossil fuel resources, although renewable energy has, particularly in recent years, started to capture a greater market share of the electric generation market.

\section{Graph 1. Percentage Electricity Generation by Energy Source, 2009}

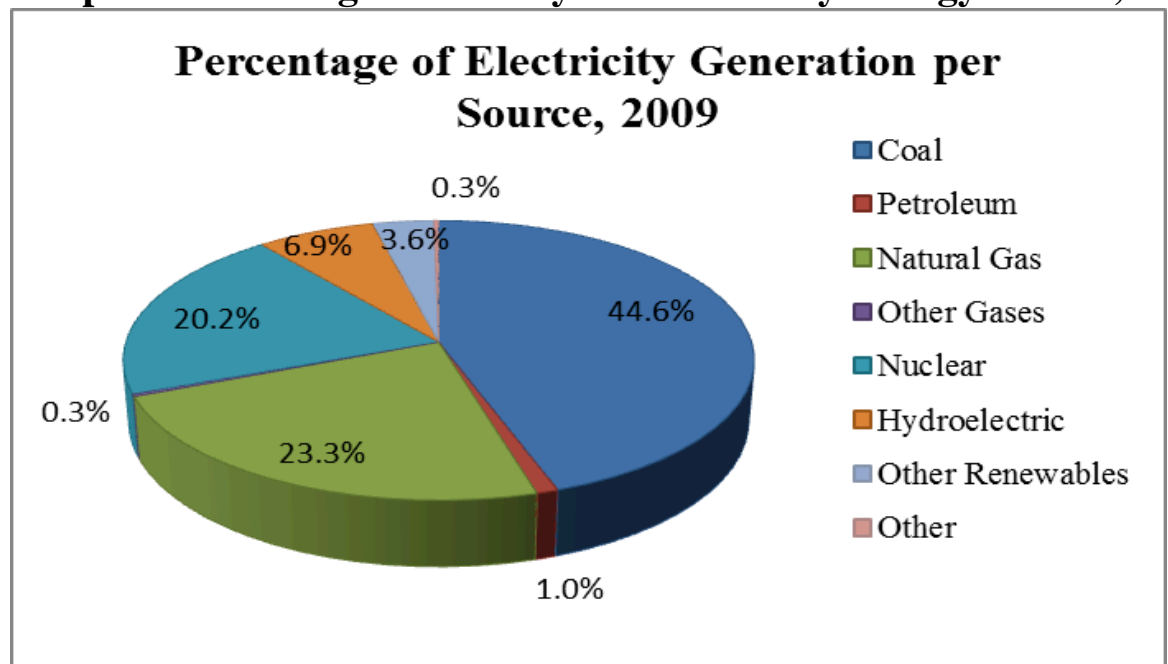

Source of data: EIA, 2010

Graph 2. Total Generation by Energy Source (in Thousand MWh), 1996-2009

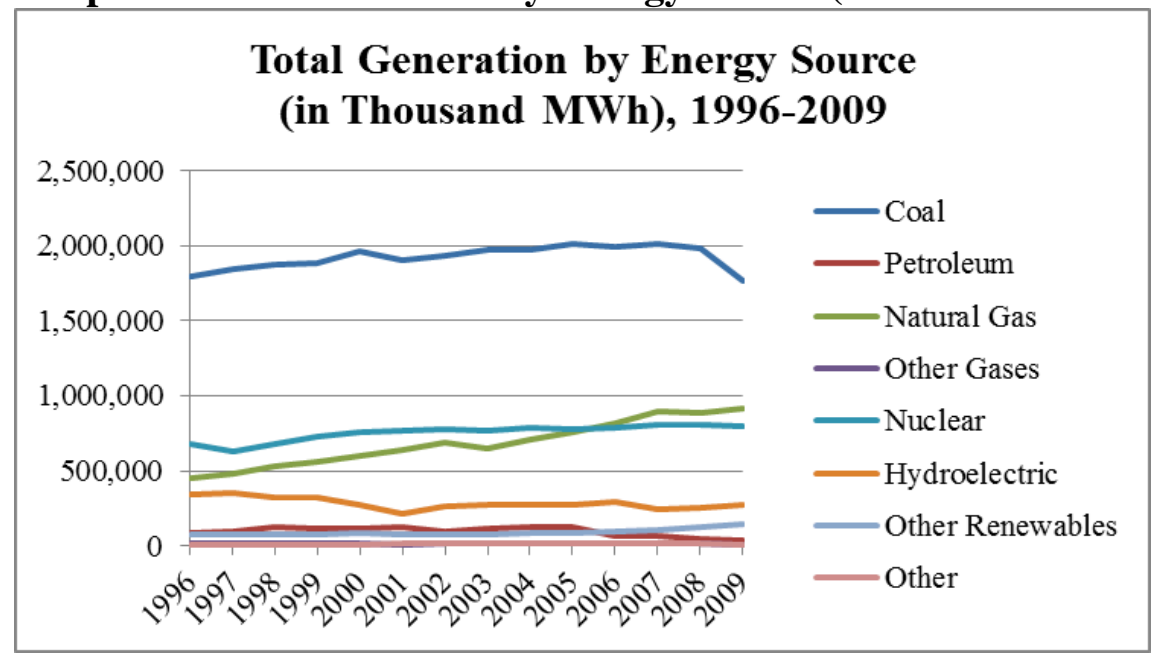


Source of data: EIA, 2010

Several trends, however, reveal that coal generation is diminishing in market size. As Graph 2 demonstrates, the percentage of coal out of the total generation has diminished over time. Graph 3, below, also reveals that coal production in the U.S. has leveled off and remained relatively flat since the late 1990s. In addition, a significant number of proposed coal generation plants proposed as of 2000 have been canceled; out of the original 36,000 MW the industry announced in 2000 that it planned to build, only 4,500 MW of capacity was built by 2007 (Shuster, 2010). Also, even though the year 2009 witnessed the largest increase in new operational coal capacity since 1991, planned coal builds took a sharp dive: out of a total of 19,520 MW of utility planned coal capacity, 4,605 MW (23.6 percent) was formally proposed and 14,915 MW (76.4 percent) was canceled (Shuster, 2010).

\section{Graph 3. U.S. Coal Production in Million Short Tons, 1950-2003}

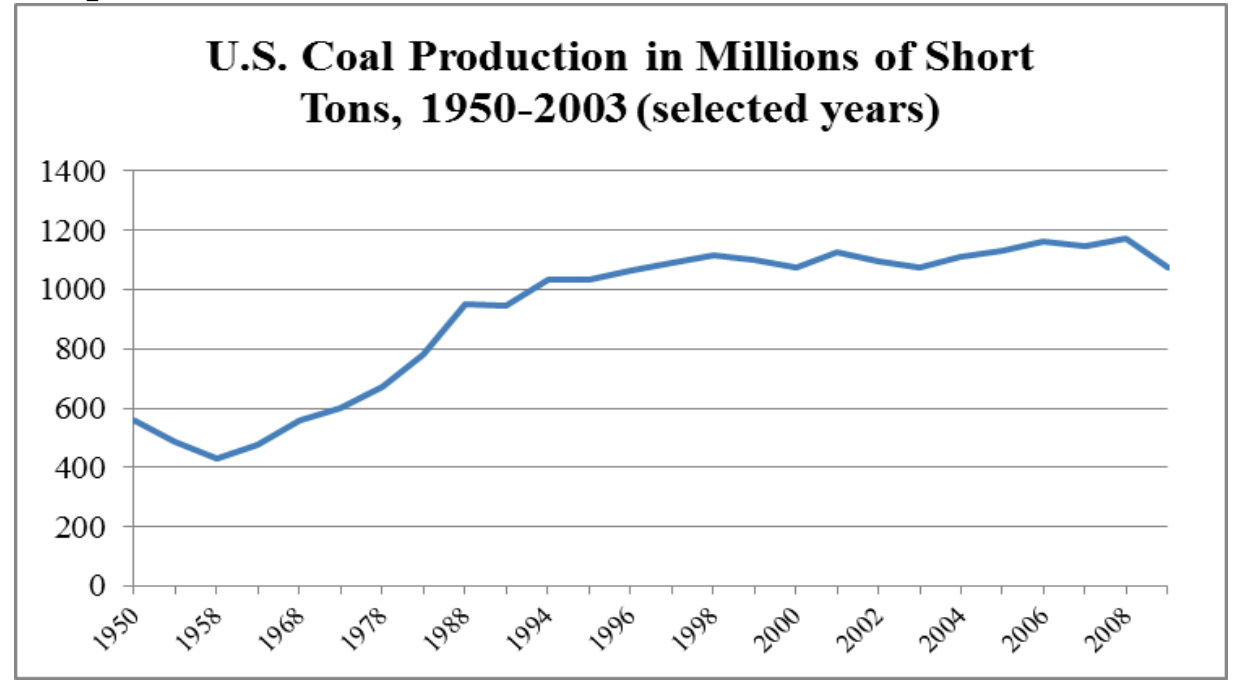

Source: EIA, 2006

Other trends indicate that the electricity sector may be moving toward greater use of renewable energy, an integration of smaller power systems with more traditional centralized units, more diverse technologies, and enhanced market competition. Wind energy development and deployment in the U.S., for instance, has increased significantly since the turn of the century; some authors contend that state energy policies played a significant role in driving this development over the past several years (Wiser and Bolinger, 2010). The average annual growth rate in wind development between 2005 and 2009 was 39 percent; and, as of the end of 2009, total wind capacity was over 35,000 MW (AWEA, 2010), up from 1,695 MW of capacity in 1999 (AWEA, 2002). The American Wind Energy Association (2010) reports that over 90 percent of all new capacity added since 2005 is either wind or natural gas. Wind capacity also accounts for roughly 64 percent of new planned capacity in 2010 and 59 percent in 2011 (Shuster, 2010). As of 2009, four states produced more than ten percent of total electricity generation from wind: Iowa (19.7\%), South Dakota (13.3\%), North Dakota (11.9\%), and Minnesota (10.7\%) (Wiser and Bolinger, 2010). 
The electricity sector of the twenty-first century has not only diversified fuel sources, it has also diversified primary market actors and traditional market relationships. In the 1990s and 2000s there has been a large increase in the number of independent, non-utility power producers. Between 1996 and 2007, independent power producers increased the percentage of total market generation that they provided from 6.3 to 38.5 percent; during this same period, independent power producers expanded the share that they provided of non-hydroelectric renewable generation from 83.7 percent to 87.4 percent (EIA, 2010b; this share reached as high as 96.1 percent in 2001). Simultaneously, mergers and acquisitions between private utility companies have increased (Byrne and Mun, 2003) and utilities have expanded to fill regional and international markets (Patterson, 1999). Regional partnerships between private utilities as well as independent power producers and non-profit organizations have increased.

The use of small-scale energy systems, owned by both utilities and end-use customers, has increased as well. The capacity of dispersed generation-distributed generation units that are not connected to the electrical grid-grew from roughly 4,000 MW to 9,700 MW between 2004 and 2008 (EIA, 2008). Distributed generation capacity grew from 5,400 to $12,900 \mathrm{MW}$ in these same years. The number of customers that participate in net metering programs has also increased; between 2004 and 2008, net metering customers increased from approximately 15,800 to 70,000 (EIA, 2010b). ${ }^{8}$

Utility-sponsored DSM programs have increased spending levels by an average of 9.2 percent annually since 1997 and, as a result, increased electricity savings by an annual average of 32.9 percent (EIA, 2010b). Utility energy efficiency programs achieved energy efficiency savings of approximately 86,000 thousand MWh in 2008 (2 percent of total generation), up from 13,300 thousand MWh in 1997 (.4 percent of total generation). Electricity savings due to utility load management programs also increased, albeit to a lesser degree, from 12,000 MW in 1997 to 13,000 MW in 2008 (EIA, 2010b).

Non-utility energy efficiency and load leveling programs have also gained momentum in recent years. Government purchasing programs for energy efficiency, for instance, have also led to substantial electricity savings and load shifting or shaving over the past decade; potential cost savings from these efforts are measured by the Consortium for Energy Efficiency as approximately one billion dollars per year across all levels of government (Harris et al., 2004). Energy efficiency service sectors, which includes a variety of occupations involved in the deployment and installation of energy efficiency products and services, are predicted to expand employment from approximately 114,000 person-years of employment (includes roughly 370,000 individuals ) in 2008 to 400,000 person-years of employment in 2020 (includes 1.3 million individuals) in 2020 (Goldman et al., 2010).

\subsection{Escaping Lock-in?}

A consideration of trends within the electricity sector over the past decade to two reveals a series of gradual changes, resulting in somewhat conflicting movements. On the one hand, the industry has experienced a flurry of activity focused on opening markets to competition. Some states have deregulated their electricity markets entirely and others have implemented partial restructuring plans. Even in regulated states, certain aspects of

\footnotetext{
${ }^{8}$ The EIA began collecting distributed generation, dispersed generation, and net metering data in form EIA-861 in 2004.
} 
the market are becoming more competitive, such as the sub-markets for ancillary services or wholesale power markets. Utilities are continually expanding their services to capture new niches within these changing markets. The entrepreneurial spirit has not only affected standard utility operations, but it has also led to the significant increase of independent power producers in electricity markets. To adapt to these changes within the market, utilities have formed power pools and trans-regional partnerships. These changes also account for the increasing number of mergers and acquisitions, and the overall concentration of market power in the hands of the few with the remaining power spread among a large number of diverse actors. In short, the electricity sector is growing more regional, and even international, in scale. Notions of competition fuel this expansion; while this expansion simultaneously encourages greater competition.

On the other hand, the electricity sector is relying on more renewable energy and energy efficiency resources and, to some degree, becoming smaller in scale. New base load power plants are smaller and more efficient than they used to be. Power operations from natural gas, the most efficient and least harmful to the environment of all fossil fuels, have steadily increased over the past five years. Wind energy capacity has grown at an extraordinary rate, although from a small base. Distributed and dispersed generation capacity has also grown in recent years (EIA, 2008). And utility-sponsored DSM programs have increased spending levels, end-user savings, and electric load savings. The industry has devoted increasing attention to renewable energy deployment, energy efficiency and conservation programs, state-led energy initiatives, and industrial and commercial adoption of combined heat and power and distributed generation units.

These two industry trends are inter-related, and are both driven by a combination of the electricity drivers examined above, including firm, market, consumer, and government level interactions. I focus my discussion on the movement toward less carbon-intensive and smaller-scale energy resources, since this trend is most directly related to Unruh's theory of carbon lock-in and may in fact represent a viable "escape" path away from lock-in; but I return to the interactions between the two movements below.

At the firm level, technological drivers have led the industry toward smaller-scale and more efficient power systems. Efficiency improvements in natural gas systems, distributed and dispersed generation units, fuel cells, and wind turbines have made smaller systems more competitive with centralized power. End-users and independent power producers are now able to own and operate their own power units and do so costefficiently (for more information on cost comparisons, see Budhraja, 1999).

At the market level, industry leadership has changed as a result of greater market competition. While a small number of IOUs control a significant portion of the market, a large number of other utility and non-utility entities exert influence as well. Independent power producers, for instance, have taken advantage of the opportunities offered by PURPA and Orders 888 and 889 by investing in non-traditional electricity sources and vying for market share. Independent power producer investments in renewable energy and distributed generation operations has helped reduce the premiums associated with these technologies, thereby making them more cost-competitive with traditional electricity sources.

At the intersection of the market and firm levels, some of the industry's largest IOUs have also contributed to changes in the market toward less carbon-intensive and 
smaller operations. Because large IOUs often cross state boundaries, any given company may face several state regulations at once, depending on the location of their service territories. For instance, one company may be required to comply with a 12.5 percent RPS goal in one state, a 20 percent goal and a net metering program in another state, and no RPS goals but an advanced IRP program in a third. Concerned about inconsistent state regulations such as these, some IOUs, though not the majority, are beginning to advocate for uniform regulations toward renewable energy and energy efficiency (see, for instance, Duke Energy's 2010 Sustainability Report (Duke Energy, 2010)). It will be less expensive, these companies argue, to gradually reduce their carbon footprints today, rather than make drastic measures to cut emissions tomorrow. Uniform standards would hold all IOUs to the same obligations, which would remove any disadvantages that currently accrue to utilities who operate in states with stricter RPS or other policy standards. National carbon standards would also help ensure a stable investment environment for alternative energy resources (Investment Summit on Climate Change, 2010).

At the government level, public involvement in the electricity sector is concentrated primarily at the state level. State governments have proactively taken the lead in energy policy. Each state has adopted a unique combination of policy incentives, regulatory measures, and voluntary initiatives that aim to diversify their electricity sectors, increase the amount of generation that comes from renewable energy, or decrease the carbon emissions that come from electricity generation. These state policies have shaped the direction of the industry significantly over the past decade. Even if the shortrun magnitude of effect on renewable energy deployment or energy efficiency developments is small, the mere adoption of these policies sends a signal to utility companies that sustainability - and, in particular, lower carbon-intensity generationmust play a larger role in the long-run structure of the industry (Rader and Norgaard, 1996), and a signal to consumers that electricity consumption is an issue that merits personal consideration in behavioral habits.

State-level participation in energy policy has initiated policy momentum at the state level. Whereas only Nevada and Iowa had RPS policies in 1997, ten states had an RPS policy by 2002, and 45 states had one by 2010 (NC Solar Center, 2010). Similar trends are noticeable for other policies as well, such as energy efficiency portfolio standards, tax incentives, net metering programs, and various subsidy programs. Policy diffusion has not only encouraged states to adopt policies that they may not have otherwise, it has also led to a steady increase in benchmark goals and other restrictions or incentives. For instance, states frequently revise their RPS design features to include higher renewable energy goals that are more commensurate with other states' benchmarks. ${ }^{9}$

\footnotetext{
${ }^{9}$ It is worth taking a moment to consider why state governments have initiated policy developments in the electricity sector. Some argue that states' activity in this realm is due to their desire to lead by example, and to demonstrate proactive leadership and public concern in absence of federal responsibility for energy or climate policy. Others would contend, however, that state leadership is also due to an expectation that has grown over the past decade of the business and economic development opportunities inherent in alternative energy developments (Rabe, 2004). Furthermore, some states actors have come to believe that energy efficiency, and possibly even renewable energy, could potentially generate more in-state economic benefits than paying rising energy costs for state or nationally imported fuels.
} 
The combination of increasingly proactive state energy policies and the regional growth of the electricity sector has generated a new variant of government involvement in the electric industry. This government involvement is geared toward carbon mitigation and has most recently burgeoned into the Regional Greenhouse Gas Initiative (RGGI). RGGI is a regional carbon cap-and-trade partnership among ten Northeast and MidAtlantic states. RGGI is an illustration of the type of innovative state policy initiative that has become increasingly prevalent over the past decade, but also relies on the benefits of regional partnerships and the flexibility of a market-based policy instrument design.

Since the initial RGGI discussions, several other regional partnerships have formed. The Western Climate Initiative, for instance, which includes seven U.S. states and four Canadian provinces, is scheduled to begin a cap-and-trade program on January 1, 2012 (Pew Center for Global Climate Change, 2010). The Midwest Greenhouse Gas Reduction Accord, signed in 2007, includes six states and one Canadian province. All Accord participants agree to reduce their greenhouse gas emissions via reduction targets, and commit to participation in an emissions tracking system (Pew Center for Global Climate Change, 2010).

The final driver of recent trends includes developments at the consumer level. Throughout the 1990s, electricity consumers were concerned primarily with the reliability of their electricity service, mainly as a result of the rolling blackouts in California and elsewhere. These concerns have encouraged a number of changes in the industry: technological improvements in transmission and distribution; the formation of independent system operators (ISOs) and regional transmission organizations (RTOs); an increase in the number of natural gas facilities to manage intermediate and peaking power loads; and the adoption of distributed generation units by commercial and industrial users to serve their own electricity needs. Throughout this same period and into the twenty-first century, a united or universal citizen movement did not support environmental concerns. Environmental coalitions were largely fractured among shorter-term issues, such as drilling for oil in the Arctic National Wildlife Refuge and campaigning for effective Corporate Average Fuel Economy standards, among others. This may perhaps explain why green marketing participation is low, despite survey results that indicate that consumers are willing to pay more for renewable energy.

More recently, however, several events have shed light on the "problem stream" (Kingdon, 1995) of global climate change. Former Vice-President Al Gore's 2006 documentary, An Inconvenient Truth, framed the issues behind climate change. Just as citizens were able to attach real images to problems of pollution in the 1960s and 1970s (Andrews, 2006), Gore's documentary evoked viewers' love of living creatures and awe for natural beauty, and effectively attached this pathos to a general concern about global warming. Concurrently, the IPCC has released their second, third, and fourth assessment reports on climate change (most recently in 2007), which reaffirm the scientific evidence behind climate change. These events have gone a long way to build citizens' understanding of the overlap between electricity and climate change. It is still too early to tell, however, whether an understanding of these issues will develop into an active citizen involvement in energy and climate change, or whether citizens will be able to maintain their focus on energy and climate when also conflicted over issues related to the economy and health care. 
Returning to the original research question, is the U.S. electricity sector on the path to escaping carbon lock-in? In consideration of some basic generation statistics, as reviewed above, it is evident that the U.S. electricity sector in its current form still relies more heavily upon carbon-emitting fossil fuels in large-scale, centralized power applications than alternative sources of generation. Renewable energy makes up a small fraction of annual electricity capacity. Distributed generation deployment rates are growing but still relatively low. Energy efficiency programs have demonstrated some reductions in peak demand and consumer energy savings but have yet to realize substantial savings as a percentage of total generation.

Yet several recent trends and other data indicate that the industry is actually growing less carbon-intensive and smaller in energy system size, and likely becoming more sustainable in operations. Crucial drivers - firm level responses to technological change, private company leadership at the market level, government intervention and policy momentum, and citizen involvement - that have traditionally shaped the structure, scale, and environmental footprint of the industry, have begun to reveal signs of change, and a divergence from the techno-institutional complex that has characterized the industry for the past 70, plus or minus, years. Technological improvements are pushing firms to invest in smaller and more efficient energy systems, as well as "smart-grid" and real-time-pricing capabilities to manage diverse electric loads. Private company leadership is driving the market toward greater market competition, regional-scale operations, and uniform environmental and energy-supply standards. Government intervention is focusing on opening markets for renewable energy competitors, encouraging and mandating energy efficiency, and crafting carbon-reduction partnerships. Policy momentum has led to an increase in state and regional energy policy incentives, and the widespread use of regulatory measures that aim to reduce market barriers to renewable energy, energy efficiency, and distributed generation deployment. Finally, citizens' insistence on electric reliability has indirectly promoted distributed generation deployment. Citizen involvement in the sector, furthermore, has recently begun to unify behind issues of climate change. If citizen involvement continues to increase in this capacity, citizens may effectively generate a political stream, which would likely compliment the state-initiated "policy stream" and the global warming "problem stream" (Kingdon, 1995). Trends indicate that a "policy window" for the development and deployment of advanced, efficient, and low- to no-carbon technologies may soon open.

A complete escape from carbon lock-in is not yet definitive. There are several indications, however, that the industry is on route to an escape from its quasi-equilibrium state through changes in energy technologies and the institutions that operate and manage the U.S. electricity system. In contrast to Unruh's theory (2002), which is upheld by others as well (March and Olsen, 1989; North, 1990; Cowan and Hultan, 1996), the findings of the present analysis reveal that an escape from lock-in may not require a "triggering" or "extraordinary" event. Instead, institutional changes can occur through the same processes that first established the equilibrium in the first place-processes that involve the firm, market, consumer, and government levels of the industry. These findings are not, however, in complete contrast to Unruh's theories on escaping carbon lock-in. Indeed, each of the three mechanisms for escaping lock-in that Unruh presents are identifiable in the historical analysis presented above: the use of policy instruments to 
encourage development and deployment of alternative energy technologies; the diffusion of information to facilitate public awareness about energy and climate issues; and the presence of some "focusing" events - which I emphasize is different than "triggering" or "extraordinary" events - to shed light on the potential long-term problems associated with the current structure and operations of the industry.

In consideration of the future of the U.S. electric industry, as argued above, this analysis concludes that there two major movements that currently dominate the industry: regional growth fueled by increased competition; and a decrease in the size and carbon intensity of average generating facilities. It will be essential to observe how these movements interact in the future. If they coordinate efforts and build integrated objectives, development within the industry may encourage a complete break from carbon lock-in. Coordination between the movements may effectively break down traditional market barriers, build regional and even international partnerships between involved stakeholders, and make non-traditional electricity sources more costcompetitive. If, instead, these trends compete for institutional resources and additionally fracture stakeholder commitment to change, the industry may struggle to maintain momentum toward the escape of carbon lock-in. These developments, however, still remain to be seen.

What will be particularly crucial to observe is whether these industry trends, are they to eventually result in a complete break from lock-in and the rejection of the U.S.'s fossil fuel economy, occur within a time frame that is at all commensurate with climate changes. Can a complete escape transpire before any significant climate disturbances occur? The industry may eventually need to make trade-offs between mitigation and adaptation, since the dual rates of change of the U.S. electricity system and the global climate system are both unfolding.

\section{Conclusion}

The present study sought to answer the research question of whether the U.S. electricity sector is on a path to escaping carbon lock-in and which factors are contributing, or have potential to contribute, to a possible escape? In addressing this question, I reviewed the history of the electricity sector from its foundations in the late nineteenth century to its advanced, quasi-equilibrium state at the end of the twentieth century, which was marked by a heavy reliance on centralized, fossil fuel-intensive electricity generation and consumption. I then identified which factors contributed most significantly to the formation of the state of carbon lock-in, and assessed the extent to which these same factors have recently contributed to a series of changes in the electricity sector.

These trends collectively reveal that the industry may in fact be on route toward escaping lock-in, although a definitive escape has not yet occurred. An escape, furthermore, may not require triggering or extraordinary events, but instead has the potential to occur via the same mechanisms and type of technological-institutional interactions that led to lock-in in the first place. The timeline for escape is not yet set, however, which leaves the lingering question, can the U.S. electricity sector break from its carbon-intensive quasi-equilibrium before any significant climate disturbances occur? 


\section{Acknowledgements}

The author would like to acknowledge the helpful contributions and insights provided by two anonymous reviewers, as well as Richard Andrews. The author is, however, solely responsible for






\section{References}

Abulfotuh, F., 2007. Energy efficiency and renewable technologies: the way to sustainable energy future. Desalination 209: 275-282.

Alanne, K., Saari, A., 2006. Distributed energy generation and sustainable development. Renewable and Sustainable Energy Reviews. 10: 539-558.

American Wind Energy Association. 2010. Windpower Outlook 2010.

American Wind Energy Association. 2002. Wind Energy Outlook 2002.

Andrews, R. N. L. 1999. Managing the Environment, Managing Ourselves. Yale University

Press: United States of America.

Bird, L., Kreycik, C., Friedman, B., October 2008. Green Power Marketing in the United States: A Status Report (11th Edition). Technical Report NREL/TP-6A2-44094.

Brennan, T., Palmer, K., Martinez, S., 2002. Implementing Electricity Restructuring: Policies, Potholes, and Prospects. Environmental and Resource Economics 22: 99-132.

Budhraja, V. S. 1999. The Future Electricity Business. The Electricity Journal.

Burtraw, D., Palmer, K., Heintzelman, M., 2000. Electricity Restructuring:

Consequences and Opportunities for the Environment. Resources for the Future Discussion Paper 00-39.

Byrne, J., Mun, Y., 2003. Rethinking reform in the electricity sector: Power

liberalisation or energy transformation? In Njeri Wamukonya, ed., Electricity Reform: Social and

Environmental Challenges. Roskilde, Denmark: UNEP-RIS $\varnothing$ Centre.

Carley, S., 2009. State renewable energy electricity policies: An empirical evaluation of effectiveness.

Energy Policy 37(8): 3071-3081.

Cowan, R., Hulten, S., 1996. Escaping lock-in: The case of the electric vehicle. Technological forecasting and social change 53 (1): 61-80.

Duke Energy, 2010. 2010 Sustainability Report. Available online at http://sustainabilityreport.dukeenergy.com/default.asp. Accessed September 17, 2010.

Flavin, C., Lenssen, N. 1994. Reshaping the electric power industry. Energy Policy 22 (12): 1029-1044.

Geller, H., 2003. Energy Revolution: Policies for a Sustainable Future. Island Press, Washington DC.

Goldman, Charles, Fuller, Merrian C., Stuart, Elizabeth, Peters, Jane S., McRae, Marjorie, Albers, Nathaniel, Lutzenhiser, Susan, Spahic, Mersiha., 2010. Energy Efficiency Services Sector: Workforce Size and Expectations for Growth. Ernest Orlando Lawrence Berkeley National Laboratory report, LBNL3987E.

Harris, Jeffrey, Brown, Matt, Deakin, John, Jurovics, Steve, Khan, Afroz, Wisniewski, Ed, Mapp, James, Smith, Barbara, Podeszwa, Melissa, Thomas, Alison., 2004. Energy-Efficient Purchasing by State and Local Government: Triggering a Landslide down the Slippery-Slope of Market Transformation.

Consortium of Energy Efficiency report.

Hirsh, Richard F. 1999. Power Loss: The Origins of Deregulation and Restructuring in the American Electric Utility System. Cambridge: The MIT Press. 
Investor Summit on Climate Change, 2010. 2010 Investor Statement on Catalyzing a Low-Carbon Economy, January 2010. United Nations Headquarters, New York City.

Joskow, Paul. 2008. Lessons Learned from Electricity Market Liberalization. The Energy Journal: 9-42.

Kingdon, J., 1995. Agendas, Alternatives, and Public Policies $2^{\text {nd }}$ Edition. New York: Longman.

Langniss, O., Wiser, R., 2003. The renewable portfolio standard in Texas: an early assessment.

Energy Policy 31 (6), 527-535.

Lasseter, R., May 2006. Dynamic Distribution using (DER) Distributed Energy Resources. Panel on Rethinking T\&D Architecture for a DER Environment: 2006 IEEE PES T \& D Meeting.

Li, X., 2005. Diversification and localization of energy systems for sustainable development and energy security. Energy Policy 33.

Lovins, A. B. 1976. Energy Strategy: The Road Not Taken? Foreign Affairs 55(1).

Lovins, A. B., et al. 2002. Small is Profitable: The Hidden Economic Benefits of Making Electrical Resources the Right Size. Snowmass, CO: Rocky Mountain Institute.

Lovins, A. 1989. The Negawatt Revolution: Solving the $\mathrm{CO}_{2}$ Problem. Keynote address at the Green Energy Conference: Montreal. Found online at http://www.ccnr.org/amory.html. Last accessed December $1,2007$.

March, J., Olsen, J., 1989. Rediscovering Institutions. Free Press, New York.

Menz, F. C., Vachon, S., 2006. The Effectiveness of Different Policy Regimes for Promoting Wind Power: Experiences from the States. Energy Policy 34, 1786-1796.

Nadel, S., Geller, H., 1996. Utility DSM: What have we learned? Where are we going? Energy Policy 24 (4): 289-302.

North Carolina Solar Center, 2010. Database of State Incentives for Renewable Energy (DSIRE). Online at http://www.dsireusa.org.

North, D., 1990. Institutions, Institutional Change and Economic Performance. Cambridge University Press, Cambridge.

Palmer, K., 1997. "Electricity restructuring: environmental impacts." Forum for Applied Research and Public Policy. 28(6).

Patterson, W., 1999. Transforming Electricity: The Coming Generation of Change. London: Earthscan Publications Ltd.

Pew Center on Global Climate Change, 2010. "Regional Initiatives.” Available online: http://www.pewclimate.org/what_s_being_done/in_the_states/regional_initiatives.cfm. Last accessed $5 / 21 / 2010$.

Rabe, B. G., 2004. Statehouse and Greenhouse: The Emerging Politics of American Climate Change Policy. Washington, DC: The Brookings Institution Press.

Rader, N. A., Norgaard, R. B., 1996. Efficiency and Sustainability in Restructured Electricity Markets: The Renewables Portfolio Standard. The Electricity Journal 9: 37-49. 
Sanyal, P., 2007. The effect of deregulation on environmental research by electric utilities. Journal of Regulatory Economics 31: 335-353.

Schumacher, E. F. 1973. Small is Beautiful: Economics as if People Mattered. Hartley \& Marks Publishers.

Shuster, E., 2010. Tracking New Coal-Fired Power Plants. National Energy Technology Laboratory presentation, January 8, 2010. Available online at http://www.netl.doe.gov/coal/refshelf/ncp.pdf. Accessed on September 17, 2010.

Smeloff, E., Asmus, P., 1997. Reinventing Electric Utilities: Competition, Citizen Action, and Clean Power. Island Press: Washington D.C.

Swezey, B., Bird, L. 2001. Utility Green Pricing Programs: What Defines Success? NREL/TP-620-29831. Golden, Colorado: National Renewable Energy Laboratory.

Thompson, B., December 2007. Meet the Maverick. Power \& Energy Magazine.

Union of Concerned Scientists. 2005. The 2005 Energy Bill. Found at http://www.ucsusa.org/clean_energy/clean_energy_policies/energy-bill-2005.html. Last accessed December 1, 2009.

Unruh, G. C., 2000. Understanding carbon lock-in. Energy Policy 28(12): 817-830.

Unruh, G. C., 2002. Escaping carbon lock-in. Energy Policy 30(4): 317-325.

U.S. Department of Energy, Energy Information Administration. October 2000. The Changing Structure of the Electric Power Industry 2000: An Update.

U.S. Department of Energy, Energy Information Administration, 2006. Coal Production in the United States: An Historic Overview. Available online at http://www.eia.doe.gov/cneaf/coal/page/coal production review.pdf. Accessed September 17, 2010.

U.S. Department of Energy, Energy Information Administration. 2008. Annual Electric Power Industry Report, Form EIA-861, 2004-2008.

U.S. Department of Energy, Energy Information Administration, 2010a. Net Generation by Energy Source: Total (All Sectors). Available online at http://www.eia.doe.gov/cneaf/electricity/epm/table1_1.html. Accessed May 24, 2010.

U.S. Department of Energy, Energy Information Administration, 2010b. Electric Power Monthly. Available online at http://www.eia.doe.gov/cneaf/electricity/epm/epm sum.html. Accessed September 17, 2010.

Wiser R., Bolinger, M., 2010. 2009 Wind Technologies Market Report. U.S. Department of Energy: Energy Efficiency and Renewable Energy document.

Wiser, R., Bolinger, M., Holt, E., Swezey, B., 2001. "Forecasting the Growth of Green Power Markets in the United States." NREL/TP-620-30101. National Renewable Energy Lab. October.

Wiser, R., Olsen, S., Bird, L., Swezey, B., 2001. Utility Green Pricing Programs: A Statistical Analysis of Program Effectiveness. NREL/TP-620-35609. Golden, Colorado: National Renewable Energy Laboratory. 